Original Research Paper

\title{
Subjective Perception and Causal Attributions for Poverty in Italy
}

\author{
Maurizio Norcia and Antonella Rissotto \\ Institute of Cognitive Sciences and Technologies-National Research Council, Via San Martino della battaglia, Rome, Italy
}

Article history

Received: 11-03-2015

Revised: 08-05-2015

Accepted: 08-05-2015

Corresponding Author:

Maurizio Norcia

Institute of Cognitive Sciences and

Technologies-National Research

Council. Via San Martino della

battaglia, Rome, Italy Tel: +3906

44595237 Fax: +390644595243

E-mail: maurizio.norcia@istc.cnr.it

\begin{abstract}
Does a relation between subjective perception of one's own socioeconomic status and what one believes about impoverishment exist? Are people's causal attributions for poverty related to their concern for cost of living, their evaluation of economic situation in the last 12 months or prevision for next 12 months? This paper aims at studying these relations in order to better understand people's viewpoint on what originates poverty. The study considers data collected into a research carried out in 2012, in Italy and that has involved around 1000 participants. A Principal Component Analysis has allowed detecting three main components and the following analyses have showed significant relations between attributions and factors like, e.g., the perception of the personal socioeconomic status and concern for cost of living.
\end{abstract}

Keywords: Poverty, Subjective Poverty, Causal Attributions for Poverty, Social Perception

\section{Introduction}

Poverty is one of the most present problems in current public debate: while the World Bank dreams $a$ world free of Poverty (WB, 2014) and keeps on producing policies and intervention to fight it, EU has proclaimed 2010 "European year for combating Poverty and Social exclusion" (EU, 2011) and has stated the fight to Poverty as one of the seven priorities of EU 2020 (EC, 2014).

Although political institutions, in the early 15 years of the third millennium, seem to mobilize against poverty, the basic question about this phenomenon is still unanswered: What is Poverty? Does anyone know an adequate definition of Poverty and the most suitable ways of measuring it?

The most usual definitions of poverty, indeed, are based primarily on poor income or assets that do not ensure physical fitness from this point of view (Guillaumont and Wagner, 2014; Turner and Lehning, 2007; Verger and Lollivier, 1999), Poverty is measured primarily through monetary well-being indicators based on income or consumptions (Van Praag and Ferrer-i-Carbonell, 2008; Green and Hulme, 2005; Woolard and Leibbrandt, 1999, Blaylock and Smallwood, 1986).

In the last decades, more complex and multidimensional visions of this economic and social phenomenon have emerged (Ravallion, 2011; Sen, 1992; 1999; Sen and Hawthorn, 1988). These approaches have bettered the understanding of Poverty, expanding this concept in many directions (for vulnerability see Gooby, 2004; Castel, 2013; Duclos et al, 2006).

Studying psychological dimension of Poverty is one of the most stimulating perspective on this topic (Misra and Tripathi, 2004; Singh and Pandey, 1990) that still owns an "enormous application potential" (Mohanty and Girishwar, 2000). Differently from 'traditional' measures of poverty, the subjective approach refers to the individual' s perception of his socio-economic status (Van Praag and Ferrer-i-Carbonell, 2008; Garner and Short, 2005; Gustafsson et al., 2004), acknowledging him as the main expert about his well-being.

The contribution given by subjective measures lies, mainly, in the opportunities of enriching our view of the phenomenon and of capturing the complexity of a person's well-being (Rojas, 2008). Furthermore, considering subjective perception of individual's status allows comparing the subjective data with objective measures of well-being derived from the data on income or consumption (Ravallion, 2008; 2010).

Despite the opportunities introduced by subjective measures, it is necessary to consider also its limitations. Firstly, the subjectivity makes difficult the interpretation and comparison of outcomes between 
different contexts. The differences in the perception of living conditions, the mix of emotional aspects, personal aspirations and expectations (Crettaz and Suter, 2013), represent some problematic issues that this approach faces. Furthermore, a great degree of variability in answers given by the same respondent if asked in different times often occurs (Kristensen and Westergaard-Nielsen, 2007; Krueger and Schkade, 2008) or individuals may not want to acknowledge their socio-economic status (Santarelli, 2013). Lastly, subjectivity and cultural influence (Santarelli, 2013) may reproduce patterns of discrimination and exclusion (for example, due to sex or ethnicity).

\section{Poverty and Attributions in Italy: Aims and Method}

This paper discusses the relation between causal attribution for poverty and how people experience some socioeconomic aspects of their life: concern for cost of living, ability to face with an unexpected expenditure of $600 €$, perceived socioeconomic status, evaluation of household's economic trend for the last 12 months and forecast for the later 12 months.

This work follows the lead of other studies that similarly have focused on relation among people's characteristics and their beliefs about impoverishment (Norcia and Rissotto, 2015; Norcia et al., 2010; 2012a; $2012 b$ ). Data analysed in this study were collected in 2012 , in Italy (Lazio) and data collection has involved almost 1000 subjects $(n=992$. See Table 1$)$.
This study aims at analysing some characteristics of people having different ideas about impoverishment. "In your opinion, why a common man gets poor?": This was the question addressed to respondents. On the other hand, the suggested attributions for poverty were: his characteristics; his behaviours; bad luck; natural disasters; other people's actions; illness/accidents; society; failures of the institutions/economic crisis. In the following step, respondents were asked to indicate their concordance rate per item, according to a 5-point Likert scale.

In order to detect possible grouping factors, a PCA has been carried out. The analysis has allowed for identifying three factors explaining an adequate amount of variance (more than $60 \%$. See Table 2 and 3 ).

The first factor can be interpreted as internal attribution (Cronbach's $\alpha=, 57$ ) and the other detected component is related to external attribution. The PCAs have furthermore allowed detecting a distinction into the external component: It emerges, namely, a first component that we could name "Powerful Others" (other people, Institutions, economic system. Cronbach's $\alpha=$ ,66) and a second component "Chance" (or, rather, what people can't control. Cronbach's $\alpha=, 63$ ).

The factor loadings let also emerge that there is no significant inverse relationship between different causal attributions: Individuals who tend, for instance, to choose internal attributions, do not necessarily choose less external explanations.

Table 1. The sample

\begin{tabular}{|c|c|c|c|c|c|c|c|c|c|c|c|c|}
\hline & \multicolumn{3}{|c|}{ Education } & \multicolumn{3}{|c|}{ Age (years) } & \multicolumn{3}{|l|}{ Sex } & \multicolumn{3}{|c|}{ Total } \\
\hline & Low & Mid & High & $0-24$ & $25-34$ & $35-44$ & $45-54$ & $55-64$ & $65+$ & M & F & \\
\hline $\mathrm{N}$ & 390 & 421 & 181 & 108 & 172 & 190 & 154 & 143 & 225 & 478 & 514 & 992 \\
\hline$\%$ & 39,3 & 42,4 & 18,2 & 10,9 & 17,3 & 19,1 & 15,5 & 14,4 & 22,7 & 48,1 & 51,9 & 100 \\
\hline
\end{tabular}

Table 2. Varimax-rotated components

\begin{tabular}{lllr} 
& & & \\
Items & Components & Chance & Internal \\
\hline Individual characteristics & Powerful others &, 060 &, 861 \\
Bad Luck &, 039 &, 501 &, 092 \\
Natural disasters &, 227 &, 830 &, 116 \\
Other people &,- 035 &, 027 &, 292 \\
Individual behaviours &, 635 &, 179 &, 735 \\
Illness &, 210 &, 716 &, 123 \\
Institutions &, 189 &, 140 &, 135 \\
Economic system &, 852 &, 153 &, 147 \\
\hline
\end{tabular}

Table 3. Components, eigenvalues and explained variance

\begin{tabular}{|c|c|c|c|c|}
\hline \multirow[b]{2}{*}{ Components } & \multicolumn{2}{|c|}{ Initial eigenvalues } & \multicolumn{2}{|c|}{ Rotation sums of squared loadings } \\
\hline & Eigenvalue & Variance $(\%)$ & Eigenvalue & Variance $(\%)$ \\
\hline Powerful others & 2,284 & 35,3 & 1,703 & 21,290 \\
\hline Chance & 1,051 & 13,14 & 1,638 & 20,475 \\
\hline Internal & ,977 & 12,22 & 1,511 & 18,888 \\
\hline Cumulative percentage of variance & & 60,65 & & 60,65 \\
\hline
\end{tabular}


The analyses shown below have tested the relationship between causal attributions grouped by the PCA and a series of independent variables: Concern for cost of living, perceived ability to face with an unexpected expenditure of $600 €$, perceived socioeconomic status, evaluation of household's economic trend for the last 12 months and forecast for the later 12 months.

As for concern for cost of living, respondents were grouped into four categories, depending on their level of worry: People not worried at all, people worried little, people rather worried and, in the last category, people very concerned for cost of living.

Regarding the question about perceived ability to face an unforeseen expenditure of $600 €$, on the other hand, people were distinguished among who considers he can afford an expenditure like this, who thinks he can't and, lastly, who has no clear idea.

As for perceived socioeconomic status, respondents were distinguished between who perceives his status as low/below the average and over the average/high.

Finally, both for evaluation of last 12 months and for forecast for the next 12 ones, three categories of responses were made: Negative evaluations/forecasts, positive evaluations/forecasts and the "I don't know" response option.

\section{Results}

\section{Concern for the Cost of Living}

Data show that, when thinking of impoverishment, people not worried for cost of living tend generally to choose more internal $(p=, 047)$ than external (powerful others/chance) explanations. On the other hand as the worry for cost of living increases, also external explanations for poverty increase $(, 000<p<, 081)$, whereas internal ones decrease (see Table 4).

\section{Could you Afford an Unexpected Expense?}

Data seem to show that people thinking not to be able to afford an unexpected expense more frequently believe that poverty is originated from external factors $(p=$ ,000). On the other hand, the same group of individuals seem to choose less frequently internal explanations, although the outcomes are not significant (see Table 5).

Table 4. Causal attributions for poverty * Concern for the cost of living

\begin{tabular}{|c|c|c|c|c|c|c|c|c|c|c|c|}
\hline & & \multirow[b]{2}{*}{$\mathrm{N}$} & \multirow[b]{2}{*}{ M } & \multirow[b]{2}{*}{ SD } & \multirow[b]{2}{*}{ SEM } & \multicolumn{6}{|c|}{ ANOVA } \\
\hline & & & & & & Variance & Sum of squares & df & Squared mean & $\mathrm{F}$ & Sign. \\
\hline \multirow[t]{5}{*}{ Internal } & Not at all & 21 & 2857 & ,46291 &, 10102 & between & 2,793 & 3 & ,931 & 2,668 & 047 \\
\hline & A little & 103 &,- 0583 & ,53916 & 05312 & within & 323,100 & 926 & 349 & & \\
\hline & Rather & 469 &, 0128 &, 60256 &, 02782 & & & & & & \\
\hline & Very worried & 337 &,- 0475 & ,59572 &, 03245 & & & & & & \\
\hline & Total & 930 &,- 0108 &, 59228 & 01942 & Total & 325,892 & 929 & & & \\
\hline \multirow[t]{5}{*}{ Powerful others } & Not at all & 21 &,- 0952 &, 53896 &, 11761 & between & 10,953 & 3 & 3,651 & 11,672 &, 000 \\
\hline & A little & 103 &,- 1553 &, 60646 & 05976 & within & 289,009 & 926 &, 313 & & \\
\hline & Rather & 465 &,- 0710 & ,53871 &, 02498 & & & & & & \\
\hline & Very worried & 339 & 1327 &, 57313 &, 03113 & & & & & & \\
\hline & Total & 928 &,- 0065 &, 56884 & 01867 & Total & 299,961 & 929 & & & \\
\hline \multirow[t]{5}{*}{ Chance } & Not at all & 21 &,- 1429 &, 72703 &, 15865 & between & 2,176 & 3 & 2,362 & 2,254 & 081 \\
\hline & A little & 103 &,- 0485 &, 45111 & 04445 & within & 296,771 & 926 &, 321 & & \\
\hline & Rather & 469 &,- 0149 &, 58268 & 02691 & & & & & & \\
\hline & Very worried & 333 & 0661 &, 56650 &, 03104 & & & & & & \\
\hline & Total & 926 &, 0076 &, 56849 &, 01868 & Total & 298,947 & 929 & & & \\
\hline
\end{tabular}

Table 5. Causal attributions for poverty * unexpected expense of $600 €$

\begin{tabular}{|c|c|c|c|c|c|c|c|c|c|c|c|}
\hline & & \multirow[b]{2}{*}{$\mathrm{N}$} & \multirow[b]{2}{*}{$\mathrm{M}$} & \multirow[b]{2}{*}{ SD } & \multirow[b]{2}{*}{ SEM } & \multicolumn{6}{|c|}{ ANOVA } \\
\hline & & & & & & Variance & $\begin{array}{l}\text { Sum of } \\
\text { squares }\end{array}$ & df & $\begin{array}{l}\text { Squared } \\
\text { mean }\end{array}$ & $\mathrm{F}$ & Sign. \\
\hline \multirow[t]{4}{*}{ Internal } & Yes & 588 &,- 0051 &, 58805 &, 02425 & between &, 272 & 2 &, 136 &, 386 &, 680 \\
\hline & No & 292 &,- 0103 & ,60629 & 03548 & within & 325,621 & 925 &, 352 & & \\
\hline & I don't know & 48 &,- 0833 & ,57735 & 08333 & & & & & & \\
\hline & Total & 928 &,- 0108 & ,59292 & 01946 & Total & 325,892 & 927 & & & \\
\hline \multirow[t]{4}{*}{ Powerful others } & Yes & 586 &,- 0631 & ,56487 & ,02333 & between & 5,125 & 2 & 2,562 & 8,022 &, 000 \\
\hline & No & 294 & ,0918 & 56193 & 03277 & within & 294,836 & 923 & ,319 & & \\
\hline & I don't know & 46 & ,0870 & 58977 &, 08696 & & & & & & \\
\hline & Total & 926 &,- 0065 &, 56946 & 01871 & Total & 299,961 & 925 & & & \\
\hline \multirow[t]{4}{*}{ Chance } & Yes & 584 &,- 0103 &, 55246 & 02286 & between &, 549 & 2 & .275 &, 853 &, 426 \\
\hline & No & 294 &, 0238 & 58079 & 03387 & within & 296,424 & 921 & ,322 & & \\
\hline & I don't know & 46 & 0870 & ,66084 & 09744 & & & & & & \\
\hline & Total & 924 & 0054 &, 56723 & 01866 & Total & 296,973 & 923 & & & \\
\hline
\end{tabular}




\begin{tabular}{|c|c|c|c|c|c|c|c|c|c|c|c|}
\hline & & \multirow[b]{2}{*}{$\mathrm{N}$} & \multirow[b]{2}{*}{$\mathrm{M}$} & \multirow[b]{2}{*}{$\mathrm{SD}$} & \multirow[b]{2}{*}{ SEM } & \multicolumn{6}{|c|}{ ANOVA } \\
\hline & & & & & & Variance & $\begin{array}{l}\text { Sum of } \\
\text { squares }\end{array}$ & $\mathrm{df}$ & $\begin{array}{l}\text { Squared } \\
\text { mean }\end{array}$ & $\mathrm{F}$ & Sign. \\
\hline \multirow[t]{3}{*}{ Internal } & Low/below the average & 674 &,- 0445 & ,59301 &, 02284 & between & 2,802 & 1 & 2,802 & 8,032 &, 005 \\
\hline & Over the average/high & 254 &, 0787 &, 58447 &, 03667 & within & 323,090 & 926 & ,349 & & \\
\hline & Total & 928 &,- 0108 & ,59292 & ,01946 & Total & 325,892 & 927 & & & \\
\hline \multirow[t]{3}{*}{ Powerful others } & Low/below the average & 672 &, 0253 &, 57851 &, 02232 & between & 2,474 & 1 & 2,474 & 7,684 &, 006 \\
\hline & Over the average/high & 254 &,- 0906 &, 53685 & 03369 & within & 297,487 & 924 & ,322 & & \\
\hline & Total & 926 &,- 0065 & ,56946 &, 01871 & Total & 299,961 & 925 & & & \\
\hline \multirow[t]{3}{*}{ Chance } & Low/below the average & 670 &, 0522 &, 58015 &, 02241 & between & 5,345 & 1 & 5,345 & 16,897 &, 000 \\
\hline & Over the average/high & 254 &,- 1181 &, 51252 &, 03216 & within & 291,628 & 922 & ,316 & & \\
\hline & Total & 924 &, 0054 & ,56723 &, 01866 & Total & 296,973 & 923 & 2,802 & & \\
\hline
\end{tabular}

Table 7. Causal attributions for poverty * evaluation of the last 12 months

\begin{tabular}{|c|c|c|c|c|c|c|c|c|c|c|c|}
\hline & & \multirow[b]{2}{*}{$\mathrm{N}$} & \multirow[b]{2}{*}{ M } & \multirow[b]{2}{*}{ SD } & \multirow[b]{2}{*}{ SEM } & \multicolumn{6}{|c|}{ ANOVA } \\
\hline & & & & & & Variance & Sum of squares & df & Squared mean & $\mathrm{F}$ & Sign. \\
\hline \multirow[t]{5}{*}{ Internal } & Improved & 41 & 0488 &, 58954 & 09207 & between &, 447 & 3 &, 149 & ,424 &, 736 \\
\hline & Stable & 438 &,- 0320 &, 58500 &, 02795 & within & 325,44 & 926 &, 351 & & \\
\hline & Worsened & 412 & 0049 & 59599 & ,02936 & & & & & & \\
\hline & I don't know & 39 & 0,0000 & 64889 & , 10390 & & & & & & \\
\hline & Total & 930 &,- 0108 & ,59228 & ,01942 & Total & 325,89 & 929 & & & \\
\hline \multirow[t]{5}{*}{ Powerful others } & Improved & 41 &,- 1951 & 60081 & 09383 & between & 4,013 & 3 & 1,338 & 4,18 &, 006 \\
\hline & Stable & 436 &,- 0505 & ,55686 &, 02667 & within & 295,95 & 924 & ,320 & & \\
\hline & Worsened & 412 &, 0485 &, 57318 &, 02824 & & & & & & \\
\hline & I don't know & 39 & , 1026 & ,55226 & ,08843 & & & & & & \\
\hline & Total & 928 &,- 0065 & ,56884 &, 01867 & Total & 299,96 & 927 & & & \\
\hline \multirow[t]{5}{*}{ Chance } & Improved & 41 &, 1463 & ,47754 &, 07458 & between & 6,947 & 3 & 2,316 & 7,31 &, 000 \\
\hline & Stable & 436 &, 0115 &, 56108 &, 02687 & within & 292,00 & 922 &, 317 & & \\
\hline & Worsened & 410 &, 0268 &, 57814 &, 02855 & & & & & & \\
\hline & I don't know & 39 &,- 3846 & ,49286 & ,07892 & & & & & & \\
\hline & Total & 926 &, 0076 & ,56849 &, 01868 & Total & 298,95 & 925 & & & \\
\hline
\end{tabular}

Table 8. Causal attributions for poverty * forecast of the next 12 months

\begin{tabular}{|c|c|c|c|c|c|c|c|c|c|c|c|}
\hline & & \multirow[b]{2}{*}{$\mathrm{N}$} & \multirow[b]{2}{*}{ M } & \multirow[b]{2}{*}{ SD } & \multirow[b]{2}{*}{ SEM } & \multicolumn{6}{|c|}{ ANOVA } \\
\hline & & & & & & Variance & Sum of squares & df & Squared mean & $\mathrm{F}$ & Sign. \\
\hline \multirow[t]{5}{*}{ Internal } & Will improve & 171 &, 1404 &, 63539 & ,04859 & between & 5,217 & 3 & 1,739 & 5,043 &, 002 \\
\hline & Will remain stable & 320 &,- 0313 &, 54193 & ,03029 & within & 318,63 & 924 &, 345 & & \\
\hline & Will worsen & 218 &,- 041 &, 62449 &, 04230 & & & & & & \\
\hline & I don't know & 219 &,- 077 &, 57342 & 03875 & & & & & & \\
\hline & Total & 928 &,- 013 & ,59106 &, 01940 & Total & 323,84 & 927 & & & \\
\hline \multirow[t]{5}{*}{ Powerful others } & Will improve & 171 &,- 0058 &, 51446 & 03934 & between & 3,293 & 3 & 1,098 & 3,412 &, 017 \\
\hline & Will remain stable & 318 &,- 0566 &, 58634 & 03288 & within & 296,67 & 922 &, 322 & & \\
\hline & Will worsen & 218 &,- 037 &, 57484 & 03893 & & & & & & \\
\hline & I don't know & 219 & 0959 &, 57064 & 03856 & & & & & & \\
\hline & Total & 926 &,- 006 &, 56946 & 01871 & Total & 299,96 & 925 & & & \\
\hline \multirow[t]{5}{*}{ Chance } & Will improve & 171 &, 0234 &, 60345 &, 04615 & between &, 225 & 3 & 075 &, 231 &, 875 \\
\hline & Will remain stable & 320 &,- 0125 &, 57631 &, 03222 & within & 298,722 & 920 &, 325 & & \\
\hline & Will worsen & 218 &, 0092 &, 55142 & 03735 & & & & & & \\
\hline & I don't know & 215 & 0233 &, 55063 & 03755 & & & & & & \\
\hline & Total & 924 &, 0076 &, 56911 & 01872 & Total & 298,95 & 923 & & & \\
\hline
\end{tabular}

\section{Perceived Socio-Economic Status}

Data about perception of socio-economic status seem to highlight similar trends as real income (Norcia, 2015; $2011 ; 2010)$ : as the subject's perceived status increases, significantly increases internal attribution for poverty $(\mathrm{p}$ $=, 005)$ and decrease external attributions $(p=, 006 ; p=$ ,000. See Table 6).

\section{Evaluation of the Last 12 Months}

Examining Table 7, some significant relations seem to emerge: people who evaluate their socioeconomic situation as stable or worsened in the last year, choose more frequently powerful others factor to explain impoverishment $(p=, 006)$. On the other hand, respondents who perceive their situation 
as improved more frequently prefer chance explanation.

How do you expect to be your Socio-Economic Situation in the Next Year?

Data show similar trends (although less pronounced) to what has emerged about evaluation of last 12 months: people who report a better outlook for the following 12 months choose more frequently internal attributions for poverty than others $(p=, 002)$. On the other hand, who expects that his socioeconomic conditions will remain stable or will even worse, chooses individualistic attributions less frequently. Outcomes about external attributions seem more difficult to be interpreted: Powerful others category is chosen little by all respondents, whereas chance attribution results to be more chosen both by people having positive and negative outlooks (see Table 8).

\section{Discussion}

In this study, causal attributions for Poverty have been correlated with some nodal aspects of people's perception of their own socioeconomic status.

Enhancing our understanding of causal attributions for Poverty, indeed, has a clear impact on policies and welfare programs. As Bradshaw (2007), indeed, "community anti-poverty programs are designed, selected and implemented in response to different theories about the causes of poverty that "justify" the community development interventions" (p. 8), or "different views about the underlying causes of poverty leads to very different policy choices" (Blank, 2003).

The first point emerging from this study is that respondents refer clearly to three main explanations for poverty. Individualistic beliefs: Fall into poverty or escaping from it is in one's power, it depends most on individual's values, choices and behaviours. On the contrary, when people believes that their socioeconomic condition originates form factors beyond their means, generally refer to two distinct groups of components: Something that you cannot change (illness, Fate, bad luck, God's will...) or that is modifiable with difficulty (Society, Economy, actions from other persons).

Going on examining results of this study, a common thread seems to emerge. People having a negative perception (justified or not) of reality around them tend to "move" the origin of one's socioeconomic situation far from the individual (other people's influence, bad luck and so on). Besides, these results are similar to what emerge crossing causal attributions with income: Low-income people choose external attributions more frequently than others (Norcia and Rissotto, 2012a, 2015; Norcia et al., 2010; 2012b; Lever and Trejo, 2004; Hayati and Karami, 2005; Morcol, 1997). Bearing in mind the intuitive relation between real income and its perceptive "neighbourhood" all the perceived socioeconomic aspects of life - a tendency to attribute events to factors beyond one's own forces seems to emerge. Hence, people who evaluate negatively the past or the following 12 months, people who perceive their socioeconomic status as low and so on, seem to activate a dynamic that could be aimed at avoiding the perception of 'failure', current or expected (i.e., if related to forecasts. See defensive externality by Hochreich, 1975).

On the contrary, who in general has opposite subjective perceptions less often identifies Poverty as a condition arising from outside individuals. Following the path of the previous reasoning, we could define as proud internality when people who self-place on a higher status position take credit for it: "I feel to be a well-off person because I am highly capable/I worked hard".

\section{Funding information}

This study was under Research Grant supported by Institute of Cognitive Sciences and Technologies at Italian National Research Council.

\section{Conflict of interest}

There is no conflict of interest.

\section{Author's Contributions}

All authors equally contributed in this work.

\section{Ethics}

This article is original and contains unpublished material. The corresponding author confirms that all of the other authors have read and approved the manuscript and no ethical issues involved.

\section{References}

Blank, R.M., 2003. Selecting among anti-poverty policies: Can an economist be both critical and caring? Rev. Soc. Economy, 61: 447-469. DOI: 10.1080/0034676032000160949

Blaylock, J.R. and D.M. Smallwood, 1986. An alternative approach to defining and assessing poverty thresholds. Western J. Agric. Econom., 11: 100-105.

Bradshaw, T.K., 2007. Theories of poverty and antipoverty programs in community development. Community Dev., 38: 7-25. DOI: $10.1080 / 15575330709490182$

Castel, R., 2013. L'insécurité sociale: Qu'est-cequ'être protégé? Seuil.

Crettaz, E. and C. Suter, 2013. The impact of adaptive preferences on subjective indicators: An analysis of poverty indicators. Soc. Indicators Res., 114: 139-152. DOI: $10.1007 / \mathrm{s} 11205-013-0388-6$

Duclos, J.Y., D. Sahn and S.D. Younger, 2006. Robust multidimensional spatial poverty comparisons in Ghana, Madagascar and Uganda. World Bank Economic Rev., 20: 91-113.

DOI: $10.1093 /$ wber/lhj005 
EC, 2014. Priorità. European Commission.

EU, 2011. European year for combating poverty and social exclusion. European Union.

Garner, T. and K. Short, 2005. Economic Well-Being Based on Income, Consumer Expenditures and Personal Assessments of Minimum Needs. 1st Edn., US Department of Labor, pp: 381.

Green, M. and D. Hulme, 2005. From correlates and characteristics to causes: Thinking about poverty from a chronic poverty perspective. World Dev., 33: 867-879. DOI: 10.1016/j.worlddev.2004.09.013

Guillaumont, P. and L. Wagner, 2014. Aid effectiveness for poverty reduction: Lessons from cross-country analyses, with a special focus on vulnerable countries. Revue d'économie du Dév., 22: 217-261. DOI: 10.3917/edd.hs01.0217

Gustafsson, B., L. Shi and H. Sato, 2004. Can a subjective poverty line be applied to China? Assessing poverty among urban residents in 1999. J. Int. Dev., 16: 1089-1107. DOI: 10.1002/jid.1127

Hayati, D. and E. Karami, 2005. Typology of causes of poverty: the perception of Iranian farmers. Journal of Economic Psychology, 26(6): 884-901.

Hochreich, D.J., 1975. Defensive externality and blame projection following failure. J. Personality Soc. Psychol., 32: 540-546. DOI: 10.1037/h0077102

Kristensen, N. and N. Westergaard-Nielsen, 2007. Reliability of job satisfaction measures. J. Happiness Stud., 8: 273-292. DOI: 10.1007/s10902-006-9027-0

Krueger, A.B. and D.A. Schkade, 2008. The reliability of subjective well-being measures. J. Public Econom., 92: 1833-1845.

DOI: 10.1016/j.jpubeco.2007.12.015

Lever, J.P. and L.M.V. Trejo, 2004. Pobreza y locus de control. Interamerican J. Psychol., 38: 225-240.

Misra, G. and K.N. Tripathi, 2004. Psychological Dimensions of Poverty and Deprivation. In: Psychology in India Revisited-Developments in the Discipline, Pandey, J. (Ed.), SAGE Publications India, New Delhi, ISBN-10: 8132103653, pp: 118-215.

Mohanty, A.K. and G. Misra, 2000. Psychology of Poverty and Disadvantage. 1st Edn., Concept Publishing Company, New Delhi, ISBN-10: 8170228050, pp: 328.

Morcol, G., 1997. Lay explanations for poverty in Turkey and their determinants. J. Soc. Psychol., 137: 728-738. DOI: $10.1080 / 00224549709595494$

Norcia, M., A. Castellani and A. Rissotto, 2010. The process of causal attribution of poverty: Preliminary results of a survey in Italy. OIDA Int. J. Sustainable Dev., 1: 85-97.

Norcia, M. and A. Rissotto, 2011. How does poverty work? Representations and causal attributions for poverty and wealth. Int. J. Soc. Sci. Humanity Stud., 3: 259-269.
Norcia, M. and A. Rissotto, 2012a. Social perception and attribution of causality for poverty: Which is the influence of thinking to myself or to others. Proceedings of the 2nd International Conference On Applied Social Science, Feb. 1-2, Information Engineering Research Institute, Kuala Lumpur, pp: 420-427.

Norcia, M., A. Rissotto and E. Noci, 2012b. Words on poverty: Preliminary research results in Italy. OIDA Int. J. Sustainable Dev., 4: 47-54.

Norcia, M. and A. Rissotto, 2015. Perceived social support and opinions on poverty: Is it chronic or transient? J. Soc. Sci., 10: 172-178. DOI: $10.3844 /$ jssp.2014.172.178

Ravallion, M., 2011. On multidimensional indices of poverty. J. Econ. Inequality, 9: 235-248. DOI: $10.1007 / \mathrm{s} 10888-011-9173-4$

Ravallion, M., 2010. Poverty lines across the world. World Bank Policy Research Working Paper Series.

Ravallion, M., 2008. Poverty lines. The New Palgrave Dictionary of Economics.

Rojas, M., 2008. Experienced poverty and income poverty in Mexico: A subjective well-being approach. World Dev., 36: 1078-1093. DOI: $10.1016 /$ j.worlddev.2007.10.005

Santarelli, E., 2013. A review of the literature on subjective poverty in Europe: A focus on data sources. Sapienza University of Rome.

Sen, A., 1999. Development as Freedom. 1st Edn., Oxford University Press, Oxford, ISBN-10: 0198297580, pp: 366.

Sen, A., 1992. Inequality Reexamined. 1st Edn., Oxford University Press, New York, ISBN-10: 0191521299, pp: 224.

Sen, A. and G. Hawthorn, 1988. The Standard of Living. 1st Edn. Cambridge University Press, Cambridge, ISBN-10: 0521368405, pp: 125.

Singh, A.K. and J. Pandey, 1990. Social support as a moderator of the relationship between poverty and coping behaviors. J. Soc. Psychol., 130: 533-541. DOI: $10.1080 / 00224545.1990 .9924615$

Turner, K. and A.J. Lehning, 2007. Psychological theories of poverty. J. Human Behav. Soc. Environ., 16: 57-72. DOI: 10.1300/J137v16n01 05

Van Praag, B. and A. Ferrer-i-Carbonell, 2008. A Multidimensional Approach to Subjective Poverty. In: Quantitative Approaches to Multidimensional Poverty Measurement, Kakwani, N. and J. Silber, (Eds.), Palgrave Macmillan, ISBN-10: 023000489X, pp: $135-154$.

Verger, D. and S. Lollivier, 1999. Pauvretés d'existence, monétaire et subjective: Facteurs de persistance et corrélations sur données de panel. Revue Économique, 50: 431-450. DOI: 10.2307/3502718

Woolard, I. and M. Leibbrandt, 1999. Measuring poverty in South Africa.

WB, 2014. Poverty overview. World Bank. 